\title{
A fast and efficient method for total DNA extraction from soil filamentous fungi
}

\author{
Un método rápido y eficiente para la extracción de ADN \\ total de hongos filamentosos del suelo \\ Wilson Huanca-Mamani ${ }^{1 *}$, Ricardo Salvatierra Martínez, \\ Germán Sepúlveda-Chavera ${ }^{1}$
}

\begin{abstract}
Extraction of high quality of DNA from fungus can be affected because the presence of the complex cell wall, high content of polysaccharides or secondary metabolites. In this research, we adapt a simple method of DNA extraction and purification of from fungus isolated from soil for Polymerase Chain Reaction (PCR) applications. The methodology described is both rapid and cost effective.

Key words: DNA extraction, fungi, soil, PCR.
\end{abstract}

\section{RESUMEN}

La extracción de ADN de alta calidad de hongos puede ser afectada debido a la presencia de una pared celular compleja, alto contenido de polisacáridos o metabolitos secundarios. En esta investigación se adaptó un simple método de extracción y purificación de ADN de hongos filamentosos aislados del suelo, para aplicaciones tipo Polymerase Chain Reaction (PCR). La metodología descrita es rápida y de bajo costo.

Palabras clave: extracción de ADN, hongos, suelo, PCR.

\section{Introduction}

Some soil filamentous fungi, like Fusarium, among other infecting a wide range of crop plants giving rise significant quantitative and qualitative losses to global agriculture (Mishra et al., 2003). The accure identification of these fungi is difficult because has traditionally been based according to morphological characters (Chen et al., 2011).

The molecular methods has emerged as a possible answer to problems associated with the fungal genetics diagnostics. Polymerase chain reaction (PCR) is a technique widely used in fungal research (Cenis, 1992) mainly for the identification of fungi, since it gives more validity to fungi identification based on both, phenotypic and genotypic attributes (Guarro et al., 1999; Ge et al., 2011). The most relevant methods used in the molecular identification of fungi are based on the variability of the ribosomal genes (White et al. 1990; Hibbett, 1992), as the internal transcribed spacer (ITS) (Gardes and Bruns, 1993). However, fungi possess cell walls made of complex structures such as chitin, glucans lipids and other polymers, which rupture of the cell wall and draw-quality DNA, which is one of the biggest challenges to generate acceptable PCR results (Karacousisa et al., 2006). There are several DNA extraction methods and the most of then are complex protocols and can may require up to several hours. Recently, Chen et al., (2011) reported a rapid method for fungal DNA extraction method, adapted from Chomczynski and Rymaszewski (2006), developed to bacterial DNA samples.

In this research, we adapt a rapid and efficient DNA extraction method, initially described in bacteria (Atashpaz et al., 2010) for species of soil filamentous fungi.

\footnotetext{
1 Facultad de Cs. Agronómicas, U. Tarapacá. Avda. General Velásquez 1775, Arica, Chile.

* Autor para correspondencia: whuanca@uta.cl
} 


\section{Materials and Methods}

\section{Fungal material}

The method was tested in the extraction of DNA of 4 species of soil filamentous: Trichoderma $s p$, Fusarium oxysporum, Penicillium sp, Paecilomyces sp. donated by the Plant Pathology group, Faculty Agronomic Sciences of the Tarapacá University, Chile, which were obtained from different soil in the Azapa Valley in Northern Chile (18 $28^{\prime} 60$ "S, 70 13'60" W). Pure cultures of each species were maintained on potato dextrose agar (PDA) at $4^{\circ} \mathrm{C}$ until use.

\section{DNA extraction pr Cedure}

Selected fungal were grown PDA. Three small lump of mycelia is added into a $1.5 \mathrm{~mL}$ Eppendorf tube by using a sterile toothpick and ground with pestle to disrupt the micelia. Then, $500 \mu \mathrm{L}$ lysis buffer (2\% CTAB, $100 \mathrm{mM}$ Tris- $\mathrm{HCl}, 1.4 \mathrm{M} \mathrm{NaCl}$, $1 \%$ PVP, $20 \mathrm{mM} \mathrm{Na}_{2}$ EDTA, $0.2 \% \mathrm{LiCl}$. The $\mathrm{pH}$ was adjusted at $\sim 8$ ) was add and ground with pestle again and incubate at $65{ }^{\circ} \mathrm{C}$ per at least $30 \mathrm{~min}$. The mixture was centrifuged at $6,160 \mathrm{~g}(10,000$ $\mathrm{rpm}$ ) for $5 \mathrm{~min}$ at room temperature (RT). The supernatant was transferred into a new tube and an equal volume of chloroform-isoamilalchol (24: $1 \mathrm{vol} / \mathrm{vol}$ ) was added. Then the tube was gently flipped several times and centrifuged at $8.870,4 \mathrm{~g}$ $(12,000 \mathrm{rpm})$ for $10 \mathrm{~min}$ at RT. The upper phase was then transferred into a new tube. An equivalent volume of cold $\left(-20^{\circ} \mathrm{C}\right)$ isopropanol was added drop-wise to precipitate the DNA (optional, store the mixture at $-20^{\circ} \mathrm{C}$ for $30 \mathrm{~min}$ ). The sample was precipitated at $12,073.6 \mathrm{~g}(14,000 \mathrm{rpm})$ for $10 \mathrm{~min}$ at RT. The supernatant was removed and $500 \mu \mathrm{L}$ of $70 \%$ ethanol $\left(4^{\circ} \mathrm{C}\right)$ was added to the sample and centrifuged at 8,870.4 $\mathrm{g}(12,000 \mathrm{rpm})$ for $5 \mathrm{~min}$. The supernatant was discarded and the pellet was dried at (RT). The pellet was dissolved in $50 \mu \mathrm{L}$ $\mathrm{H}_{2} \mathrm{Odd}$ and DNA solution was stored at $-20{ }^{\circ} \mathrm{C}$.

\section{PCR condition}

Each total DNA was amplified by PCR in a final volume of $20 \mu \mathrm{L}$. The PCR reactions were performed using the ITS primers reported by White et al. (1990) (IST3; 5'-GCATCGATGAAGAACGCAGC-3' and ITS4; 5'-TCCTCCGCTTATTGATATGC-3'). Each reaction contained $2 \mu \mathrm{L}$ of fungal DNA extraction, 10 pmoles of aech primer, $2,5 \mathrm{mM}$ of aech dNTP, $2 \mathrm{mM} \mathrm{MgCl} 2,1$ X PCR buffer $(\mathrm{KCl}), 1$ units of Taq DNA polymerase (Thermo Scientific) and sterile distilled water. Cycling conditions were: 5 min at $94 \mathrm{C} ; 35$ cycles of $30 \mathrm{sec}$ at $94{ }^{\circ} \mathrm{C} ; 30 \mathrm{sec}$ at $55 \mathrm{C} ; 30 \mathrm{sec}$ at $72 \mathrm{C}$ and final elongation step of $2 \mathrm{~min}$ at $72 \mathrm{C}$. PCR blank reactions controls were incorporated. Three $\mu \mathrm{L}$ of each PCR product was visualised on 1,5\% agarosa gels stained with gel-red (Biotium).

\section{Results and Discussion}

Most common problems identified for the isolation and purification of DNA from fungi isolated from soil include degradation of DNA owing to endonucleases, high production of polysaccharides and the presence of inhibitor compounds such as secondary metabolites that can reduce yield and purity by binding covalently with the extracted DNA (Möller et al., 1992).

In this research we adapted a rapid and efficient DNA bacterial method for fungi isolated from soil (Atashpaz et al., 2010). This short protocol combines inactivation of proteins with precipitation of acidic polysaccharides by hot CTAB in presence of high salts and only a single selective precipitation of DNA with isopropanol and it is appropriate for simultaneous processing of many samples because all steps can be done in Eppendorf tubes. The growth of mycelia on Petri dishes eliminates the need for still of shaking liquid cultures. The whole procedure can be completed within an hour and is applicable to wide variety of soil fungi including Trichoderma sp, Fusarium oxysporum, Penicillium sp and Paecilomices sp. Figure 1 shows the results of the separation of the extracted DNA on a $1 \%$ agarose gel, stained with Gel-Red (Biotium) and visualized under UV light. The methods here reported yields high-quality DNA, which is transparent, nonviscous, lacks visible contamination of RNA and non-degradation DNA was observed.

DNA yields obtained using this method ranged 400 to $900 \mathrm{ng} / \mathrm{uL}$ with an $\mathrm{A}_{260} / \mathrm{A}_{280}$ ratio close to 1,9 and $\mathrm{A}_{260} / \mathrm{A}_{230}$ around 1,7 indicating very little contamination of proteins, polysaccharides or aromatic compounds and may be used for further PCR analysis.

In order to check the efficiency and realibility of this method, the 18S rRNA genes of the ITS 


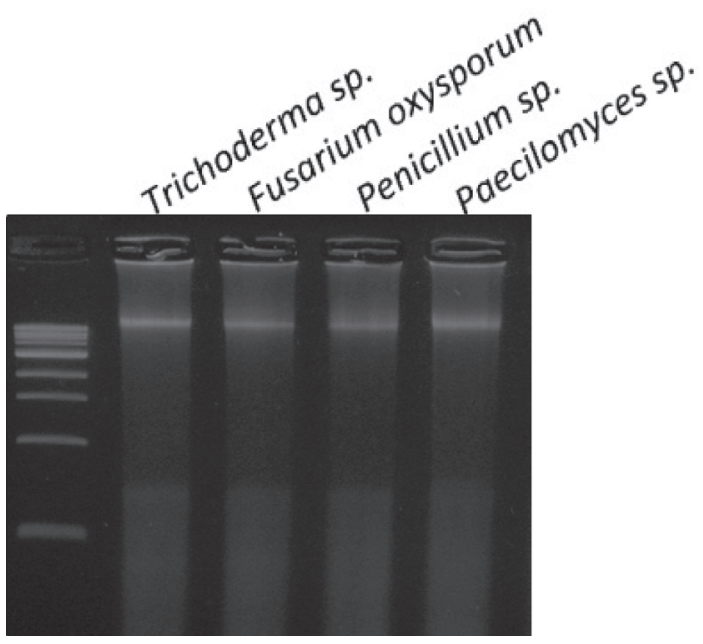

Figure 1. Total genomic DNA extracted from several fungi isolated from soil. DNAs were visualised in $1 \%$ agararose gel and stained with Gel-Red. M: 1 Kb DNA Ladder.

region were amplified by PCR (Figure 2). Using the ITS3/ITS4 primers, a single band of approximately between 300 and $400 \mathrm{bp}$ is obtained for all strain, however an additional band of approximately 250 bp in observed in Trichoderma sp. (Figure 2). It is likely that this robust procedure could be applied to the examination of many other fungal cultures and, possibly, clinical specimens. It provides a rapid, reliable, and low cost alternative to the existing

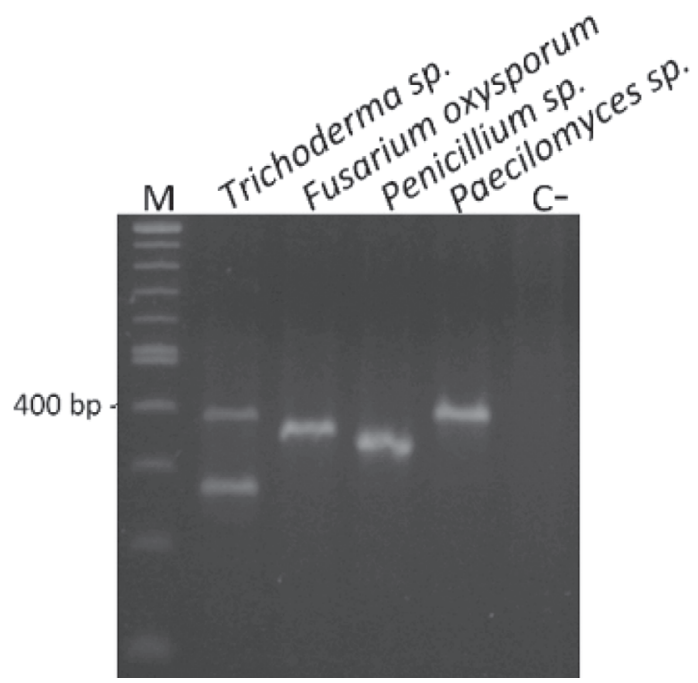

Figure 2. DNA amplification by PCR of the ITS products obtained with ITS3/ITS4 primers. PCRs products from several fungi isolated from soil were visualised in $1 \%$ agararose gel and stained with Gel-Red. M: 100 pb DNA Ladder. C-: Negative control.

DNA purification protocols used in molecular biology research.

\section{Acknowledgments}

This research was supported by Convenio de Desempeño UTA-MECESUP-2, Foundation for Agrarian Innovation (FIA) PYT-Project 2012-0024 and Mayor-UTA Proyect Mayor-9711-13.

\section{Literature Cited}

Atashpaz, S.; Khani S.; Barzegari, A.; Barar, J.; Vahed, S.Z.; Azarbaijani, R.; Omidi, Y.

2010. A robust universal method for extraction of genomic DNA from bacterial species. Mikrobiologiia, 79: 562-566.

\section{Cenis, J.L.}

1992. Rapid extraction of fungal DNA for PCR amplification. Nucleic Acids Research, 20: 2380.

Chen, Y.; Prior, B.A.; Shi, G.; Wang, Sh.

2011. A rapid PCR-Based approach for molecular identification of filamentous fungi. J. of Microbiol., 49: 675-679.

Gardes, M.; Bruns, T.D.

1993. ITS primers with enhanced specificity for basidiomycetesapplication to the identification of mycorrhizae and rusts. Mol. Ecol., 2: 113-118.

Ge, Y.P.; Wang, L.; Lu, G.X.; Shen, Y.N.; Liu, W.D.

2012. A simple and reliable PCR-restriction fragment length polymorphism assay to identify Candida albicans and its closely related Candida dubliniensis. Brazilian Journal of Microbiol., 43: 873-879.
Guarro, J.; Gene, J.; Stchigel, A.M.

1999. Developments in fungal taxonomy. Clin. Microbiol. Rev., 12: 454-500.

Hibbett, D.S.

1992. Ribosomal RNA and fungal systematics. Trans. Mycol. S C. Japan, 33: 533-556.

Karakousisa, A.; Tana, L.; Ellisb, D.; Alexioub, H.; Wormald, P.J. 2006. An assessment of the efficiency of fungal DNA extraction methods for maximizing the detection of medically important fungi using PCR. J. Microbiology Methods, 65: 38-48.

Mishra, P.K.; Fox, R.T.; Culham, A.

2003. Development of a PCR-based assay for rapid and reliable identification of pathogenic Fusaria. FEMS Microbiol Lett., 218: 329-332.

O’Donnell, K.; Cigelnik, E.; Casper, H.H.

1998. Molecular phylogenetic, morphological and mycotoxin data support re-identiccation of the quorn mycoprotein fungus as Fusariumven enatum. Fungal Genet. Biol., 23: 57-67. 
White, T.J.; Bruns, T.D.; Lee, S.; Taylor, J.W.

1990. Amplification and direct sequencing of fungal ribosomal RNA genes for phylogenetics. PCR Prot Cols: A Guide to Methods and Applications, pp. 316-317. In: M.A. Innis, D.H. Gelfand, J.J. Sninsky, and T.J.White (eds). Academic Press, Inc., Harcourt Brace Jovanovich, New York, NY, USA. pp. 461.
Möller, E.M.; Bahnweg, G.; Sandermann, G.; Geiger, H.H. 1992. A simple and efficient prot $\mathrm{Col}$ for isolation of high molecular weight DNA from filamentous fungi, fruit bodies, and infected plant tissues. Nucleic Acids Research, 20: 6115-6116. 